\title{
TĖVŲ, AUGINANČIU CEREBRINIU PARALYŽIUMI SERGANČIUS MOKYKLINIO AMŽIAUS VAIKUS, PSICHOEMOCINĖS BŪKLĖS IR GYVENIMO KOKYBE்S SĄSAJOS
}

\author{
Rūta Dadeliene் ${ }^{1}$, Evelina Bartoševič ${ }^{1}$, Jonas Kairys ${ }^{1,2}$, Rasa Barčyte் ${ }^{1,2}$, Juozas Raistenskis ${ }^{1,2}$ \\ ${ }^{1}$ Vilniaus universiteto Medicinos fakulteto Sveikatos moksly institutas, \\ ${ }^{2}$ Vaiku ligonine, Vilniaus universiteto ligoninès Santaros kliniku filialas
}

Raktažodžiai: vaikai su cerebriniu paralyžiumi, tėvai, gyvenimo kokybè, psichoemocinè būklè, sąsajos.

\begin{abstract}
Santrauka
Darbo tikslas - atskleisti tėvų, auginančių cerebriniu paralyžiumi sergančius mokyklinio amžiaus vaikus, psichoemocinès būklès ir gyvenimo kokybès sąsajas. Tyrimo metodai. Tyrime dalyvavo 68 tevai, auginantys cerebriniu paralyžiumi sergančius mokyklinio amžiaus vaikus. Taikytas Šeimų gyvenimo kokybės klausimynas ir Nuotaikos profilio skalès klausimynas. Duomenų analizei naudotas statistinès analizès R paketas ir Excel 2010 programa.

Rezultatai ir išvados. Tẻvų, auginančių cerebriniu paralyžiumi sergančius mokyklinio amžiaus vaikus, psichoemocinè būklè buvo stabili. Nei vienam iš tèvų nebuvo nustatytas stiprus psichoemocinès būsenos sutrikimas. Nustatyta, kad tẻvų, auginančių cerebriniu paralyžiumi sergančius mokyklinio amžiaus vaikus, gyvenimo kokybe buvo patenkinama. Geriausiai tèvai vertino savo šeimos tarpusiavio sąveikos sriț, o blogiausiai - emocinès gerovès sritį. Nustatytos silpnos teigiamos tiesinès statistiškai reikšmingos sąsajos tarp tėvų, auginančių cerebriniu paralyžiumi sergančius vaikus, materialinès gerovės ir gyvenimo kokybės $(r=0,37, p=0,002)$, šeimos tarpusavio sąveikos ir didesnès gaunamos paramos $(\mathrm{r}=0,30, \mathrm{p}=0,010)$ $(p \leq 0,05)$ bei emocinès gerovès ir šeimos tarpusavio sąveikos $(\mathrm{r}=0,31)(\mathrm{p} \leq 0,05)$.
\end{abstract}

\section{Ivadas}

Vienas iš labiausiai paplitusių vaikų nervų sistemos susirgimų, sukeliančių neiggalumą net 88,7 proc. atvejų, yra vaikų cerebrinis paralyžius (toliau - VCP). Nustatyta, kad šios patologijos paplitimas pasaulyje sudaro 2-2,5 atvejų iš 1000 naujagimių. Lietuvoje vaikų sergamumas VCP sudaro
2,3 atvejų iš 1000 naujagimių [1,2]. Labiausiai paplitusios spazminès šios patologijos formos, kurioms tenka iki 80-85 proc. visų VCP atvejų [3].

VCP sukelia specifini judesio koordinacijos ir pažintinių funkcijų sutrikimų simptomų kompleksą, kuris gali stipriai paveikti vaiko protinius, socialinius, komunikacinius gebejjimus ir visos šeimos gyvenimo kokybę [4-6]. Tẻvai ir jų cerebriniu paralyžiumi sergantys vaikai patiria ịvairaus pobūdžio specialiujų poreikių tenkinimo sunkumų bei problemų. Šiuo atveju iš esmès pasikeičia vidinis ir socialinis šeimos gyvenimas, ịprastinis gyvenimo ritmas, psichologinis klimatas, blogejja tẻvų emocinè būklè $[7,8]$. Tèvai patiria psichinę ịtampą, kurią kai kurie tyrèjai ịvardina kaip „tėvų stresą“, kuris trunka ilgus metus - tampa lètiniu [9]. Yra atlikta mokslinių tyrimų, nagrinėjančių specialiuosius cerebriniu paralyžiumi sergančių vaikų poreikius, tačiau trūksta mokslinès literatūros, nagrinejjančios tėvų, auginančių cerebriniu paralyžiumi sergančius mokyklinio amžiaus vaikus, gyvenimo kokybę ir psichoemocinę būseną.

Darbo tikslas - atskleisti tėvų, auginančių cerebriniu paralyžiumi sergančius mokyklinio amžiaus vaikus, psichoemocinès būklès ir gyvenimo kokybès sąsajas.

\section{Tyrimo organizavimas ir metodika}

Tyrimas atliktas viešosios ịstaigos Vilniaus universiteto ligoninès Santaros klinikų filialo Vaikų fizinès medicinos ir reabilitacijos skyriuje, Vilniaus dienos socialinès globos centre „Čiauškutis“, Vilniaus miesto vaikų ir jaunimo pensionate, Vilniaus „Šilo“ specialiojoje mokykloje, Vilniaus „Vilties” specialiojoje mokykloje ir daugiafunkciniame centre bei Kauno specialiojoje mokykloje. Tyrime dalyvavo 68 tėvai, auginantys 12-17 metų vaikus, sergančius spastine cerebrinio paralyžiaus forma. Vaikų gebejimai pagal TLK10-AM diagnostinius kriterijus atitinka vidutinị lygi ( $>6$ balai). Tiriamujjų amžiaus vidurkis $-38,02 \pm 7,98$ metai. Iš jų 61 motina ( 90 proc.) ir 7 teěriai (10 proc.). Dauguma tyrime 
dalyvavusių tėvų (68,1 proc.) turèjo darbą.

Gyvenimo kokybei ịvertinti buvo taikomas Šeimų gyvenimo kokybės klausimynas (angl. Family quality of life scale, FQOL), sudarytas iš 25 uždarų klausimų [10]. Kiekvienas klausimas vertintas pagal Likert 5 balų skalę, nuo „Tikrai ne“ (1 balas) iki „Tikrai taip“ (5 balai). Uždaro tipo klausimai padalinti i 5 gyvenimo kokybès sritis: šeimos tarpusavio sąveika (santykiai), (1, 7, 10-12, 18 klausimai); auklèjimas, $(2,5,8,14,17,19$ klausimai); emocinè gerovè, $(3,4,9,13$, klausimai); fizinè(materialioji) gerovè $(6,15,16,20,21$ klausimai); parama neigaliam šeimos nariui (22-25 klausimai).

Psichoemocinè būklè buvo vertinama pagal Nuotaikos profilio skalès klausimyną (angl. Profile of mood state, toliau -POMS) [11]. Skalè apima tiriamojo 65 ypatybių įvertinimą balais (nuo 0 iki 4) pagal tos ypatybès stiprumą. Gaunami emocinès būklès ịvertinimai pagal šešis aspektus: ịtampanerimas, depresiškumas-liūdesys, pyktis-priešiškumas, energija-aktyvumas, nuovargis-inercija, sumišimas-suglumimas. Kuo daugiau balų surenkama, tuo labiau išryškejjęs požymis.

Duomenų analizé buvo atliekama naudojant statistinès analizès R paketą ir Excel 2010 programą. Buvo skaičiuojama: imties vidurkis $(\mathrm{X})$, vidurkio standartinis nuokrypis $( \pm \mathrm{SN})$, duomenų procentinè išraiška (\%). Normalumo skirstinys buvo skaičiuojamas Shapiro-Wilk testu. Imtys buvo lyginamos naudojantis Wilcoxon ženklų kriterijumi, kai duomenys netenkino normalumo sąlygos ir Student t-kriterijumi, kai duomenys normalumo sąlygą tenkino. Koreliacijos ryšiui nustatyti buvo skaičiuojamas Spearman ir Pearson koreliacijos koeficientas (r). Statistinių hipotezių tikrinimui pasirinktas reikšmingumo lygmuo $(\mathrm{p} \leq 0,05)$.

\section{Tyrimo rezultatai}

Nei vienam iš tèvų nebuvo nustatytas stiprus psichoemocinès būsenos sutrikimas. Sudejus ịtampos-nerimo, depresiškumo-liūdesio, pykčio-priešiškumo, nuovargio-inercijos, sumišimo-suglumimo būsenų vidurkius ir atėmus energijosaktyvumo vidurkị, buvo apskaičiuotas bendras psichoemocinès būklès balas. Gautų balų vidurkis $38,71 \pm 2,56$ pagal POMS testą leidžia teigti, kad respondentų psichoemocinè būklè yra pakankamai stabili.

Nustatyta, kad negalią turinčių vaikų šeimos dažnai susiduria su daugeliu sunkumų, kurie daro ịtaką ir tèvų tarpusavio santykiams. Pilnoje šeimoje gyvenantys tèvai, lyginant su tais, kurie augina neigalų vaiką gyvendami atskirai, yra linkę skirstyti atsakomybę už vaiko ugdymą tarpusavyje. Mūsų tyrime 25 proc. respondentų, dalyvavusių apklausoje, buvo išsiskyrę, vieniši arba našliai. Tyrimo rezultatai parodè, kad psichoemocinė būklė neženkliai dažniau buvo sutrikusi vienišiems tèvams, auginantiems neiggalų vaiką, skirtumas tarp tyrimo duomenų yra nepatikimas (1 lentelè).

Depresiškumo-liūdesio būsena vienišiems tèvams pasireiškẻ reikšmingai dažniau $(14,88 \pm 0,31$ balų) nei tèvams, kurie vaiką augino poroje $(8,94 \pm 0,40$ balai), $(\mathrm{p} \leq 0,05)$. Pyktis-priešiškumas taip pat pasireiškẻ dažniau vienam iš tèvų auginant neigalų vaiką $(11,65 \pm 0,28$ balų), nei poroje-(7,53 $\pm 0,33$ balai), $(\mathrm{p} \leq 0,05)$. Kitu emocijų būsenų skirtumai skyrèsi statistiškai nereikšmingai.

Tyrimo metu buvo atskleista, kad nèra statistiškai reikšmingo skirtumo tarp tèvų, gyvenanačių kaimo ar miesto vietovėse, psichoemocinès būklès. Mieste gyvenančių tèvų psichoemocinè būklè nèra reikšmingai stabilesnè nei tėvų, gyvenančių kaime.

Ivertinus cerebriniu paralyžiumi sergančių mokyklinio amžiaus vaikų
1 lentelè. Psichoemocinès būklès vertinimas, priklausomai nuo šeimos sudėties (balais)

\begin{tabular}{|l|c|c|c|c|c|}
\hline Psichoemocinė būsena & $\begin{array}{c}\text { Inter- } \\
\text { valas }\end{array}$ & $\begin{array}{c}\text { Šeimoje yra } \\
\text { vienas iš tèvų } \\
(\mathbf{X} \pm \mathbf{S N})\end{array}$ & $\begin{array}{c}\text { Šeimoje yra } \\
\text { abu tèvai } \\
(\mathbf{X} \pm \mathbf{S N})\end{array}$ & $\begin{array}{c}\text { Skir- } \\
\text { tumas }\end{array}$ & $\begin{array}{c}\mathbf{p} \\
\text { reikšmè }\end{array}$ \\
\hline Itampa-nerimas & $0-36$ & $11,53 \pm 0,74$ & $10,76 \pm 0,73$ & 0,78 & 0,362 \\
\hline Depresiškumas-liūdesys & $0-60$ & $14,88 \pm 0,31$ & $8,94 \pm 0,40$ & 5,95 & 0,007 \\
\hline Pyktis-priešiškumas & $0-48$ & $11,65 \pm 0,28$ & $7,53 \pm 0,33$ & 4,12 & 0,012 \\
\hline Energija-aktyvumas & $0-32$ & $14,71 \pm 0,52$ & $14,76 \pm 0,90$ & 0,06 & 0,528 \\
\hline Nuovargis-inercija & $0-28$ & $10,12 \pm 0,86$ & $8,29 \pm 0,82$ & 1,72 & 0,749 \\
\hline Sumišimas-suglumimas & $0-28$ & $8,06 \pm 0,49$ & $6,00 \pm 0,39$ & 2,05 & 0,122 \\
\hline Bendras & $0-200$ & $39,59 \pm 2,64$ & $35,24 \pm 3,06$ & 2,45 & 0,179 \\
\hline
\end{tabular}

3 lentelè. Skirtingos šeimininès sudèties tėvų gyvenimo kokybės sričių tyrimo rezultatai $(\mathrm{X} \pm \mathrm{SN})$

2 lentelè. Tėvų gyvenimo kokybės sričių tyrimo rezultatai

\begin{tabular}{|l|l|}
\hline Gyvenimo kokybės sritys & $\mathbf{X} \pm \mathbf{S N}$ \\
\hline Šeimos tarpusavio sąveikia & $4,04 \pm 0,10$ \\
\hline Auklèjimas & $4,02 \pm 0,11$ \\
\hline Emocinė gerovė & $3,14 \pm 0,45$ \\
\hline Fizinė gerove் & $3,99 \pm 0,10$ \\
\hline Parama & $3,92 \pm 0,11$ \\
\hline
\end{tabular}

\begin{tabular}{|l|c|c|c|c|}
\hline Gyvenimo kokybės sritys & $\begin{array}{c}\text { Šeimoje yra } \\
\text { vienas iš } \\
\text { tèvų (balai) }\end{array}$ & $\begin{array}{c}\text { Šeimoje yra } \\
\text { abu tèvai } \\
\text { (balai) }\end{array}$ & $\begin{array}{c}\text { Skirtu- } \\
\text { mas } \\
\text { (balais) }\end{array}$ & $\begin{array}{c}\mathbf{p} \\
\text { reikšmè }\end{array}$ \\
\hline Šeimos tarpusavio sąveikia & $3,79 \pm 0,19$ & $4,25 \pm 0,16$ & 0,46 & 0,006 \\
\hline Auklėjimas & $3,83 \pm 0,19$ & $4,2 \pm 0,19$ & 0,34 & 0,024 \\
\hline Emocinė gerovė & $2,99 \pm 0,53$ & $3,09 \pm 0,61$ & 0,10 & 0,885 \\
\hline Fizinė gerovė & $3,87 \pm 0,20$ & $4,14 \pm 0,20$ & 0,27 & 0,071 \\
\hline Parama & $3,97 \pm 0,22$ & $3,87 \pm 0,15$ & 0,10 & 0,380 \\
\hline
\end{tabular}




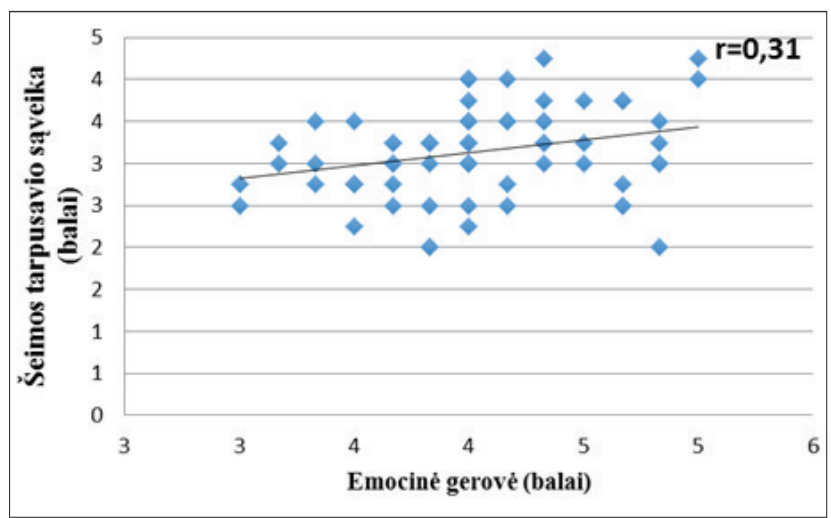

1 pav. Tèvų emocinès gerovès ir šeimos tarpusavio sąveikos priklausomybè

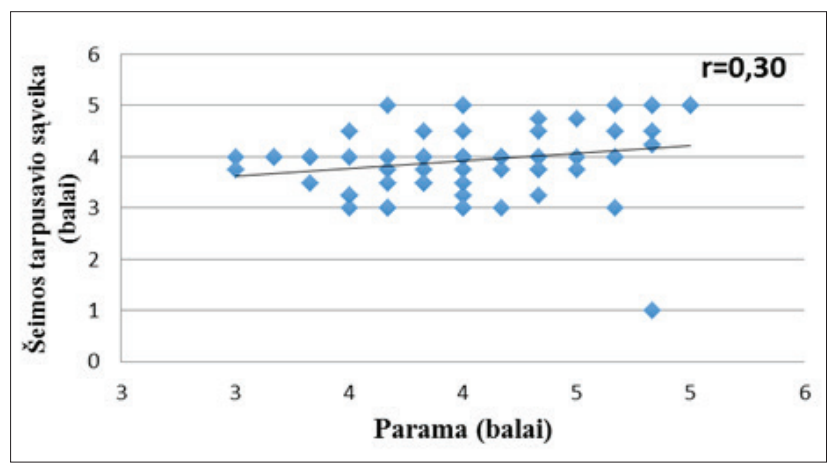

2 pav. Tèvų gaunamos paramos ir šeimos tarpusavio sąveikos priklausomybė

tėvų gyvenimo kokybę, gauti rezultatai parode, jog jų gyvenimo kokybè buvo patenkinama (vidutinè). Geriausiai tèvai ịvertino savo šeimos tarpusavio sąveiką (4,04 $\pm 0,10$ balai) ir vaikų auklejjimą $(4,02 \pm 0,11$ balai). Prasčiausiai $(3,14 \pm 0,45$ balo) tèvai ịvertino emocinès gerovès sriti ( 2 lentelè).

Šeimos tarpusavio sąveika ir auklejjimas statistiškai reikšmingai skiriasi skirtingos sudèties šeimų grupèse $(\mathrm{p} \leq 0,05)(3$ lentelè). Fizinè, emocinè gerovè ir parama tarp šių tiriamujų grupių statistiškai reikšmingai nesiskiria.

Išanalizavus tėvų, gyvenančių skirtingose vietovèse, gyvenimo kokybės sritis, gauti rezultatai rodo, kad šeimų tarpusavio sąveikos, auklëjimo ir fizinès gerovès duomenų vidurkiai mieste gyvenančių tiriamujų buvo statistiškai reikšmingai $(p \leq 0,05)$ didesni, nei kaime gyvenančių tiriamụjų.

Buvo apskaičiuoti koreliacijos koeficientai tarp tėvų gyvenimo kokybės subskalių. İvertinus sąsajas tarp šių skalių nustatyta, kad tėvų, auginančiu cerebriniu paralyžiumi sergančius mokyklinio amžiaus vaikus, emocinè gerovè statistiškai reikšmingai koreliuoja su šeimos tarpusavio sąveika $(\mathrm{r}=0,31)(\mathrm{p} \leq 0,05)(1 \mathrm{pav})$.

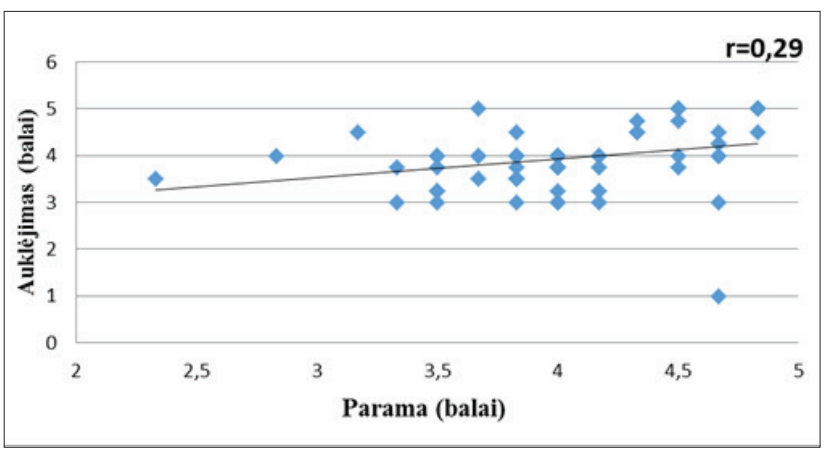

3 pav. Tèvų gaunamos paramos ir vaikų auklejjimo sąsajos

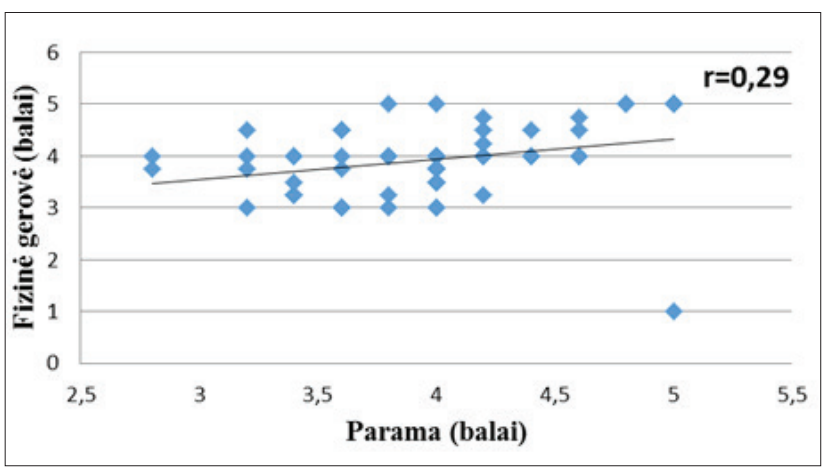

4 pav. Tẻvų gaunamos paramos ir vaikų auklëjimo priklausomybė

Silpna teigiama koreliacija ir statistiškai patikimas ryšys gautas tarp šeimos tarpusavio sąveikos ir didesnès gaunamos paramos $(\mathrm{r}=0,30) \quad(\mathrm{p} \leq 0,05)(2 \mathrm{pav})$.

Silpnos teigiamos tiesinès statistiškai reikšmingos sąsajos buvo tarp tėų emocinès gerovès ir vaikų auklèjimo $(\mathrm{r}=0,25)$ $(p \leq 0,05)$ ir tarp didesnès teikiamos paramos ir vaikų auklèjimo $(r=0,29)(\mathrm{p} \leq 0,05) \quad(3$ pav $)$.

Fizinè (materialioji) gerovè taip pat susijusi su tèvų, auginančių cerebriniu paralyžiumi sergančius mokyklinio amžiaus vaikus, emocine gerove $(\mathrm{r}=0,25)(\mathrm{p} \leq 0,05)$. Silpna, teigiama, statistiškai reikšminga sąsaja nustatyta tarp fizinès gerovès ir gaunamos paramos $(\mathrm{r}=0,29)(\mathrm{p} \leq 0,05)(4 \mathrm{pav})$.

Šis tyrimas neatskleidè reikšmingų sąsajų tarp psichoemocinès būklès ir gyvenimo kokybès.

\section{Rezultatų aptarimas}

Autorių duomenimis, motina dažniau prisiima pirminę naštą, atsakomybę už vaikų su negalia priežiūrą, negu tèvas $[12,13]$. Tokia tèvų, auginančių cerebriniu paralyžiumi sergančius mokyklinio amžiaus vaikus, pasiskirstymo pagal lytị tendencija buvo ir mūsų tyrime: motinų buvo daugiau (90 proc.), nei tèčiu (10 proc.). Viena iš labiausiai paplitusių cerebrinio paralyžiaus formų, kuri sutinkama maždaug 40 proc. visų VCP spastinių formų, yra spazminè diplegija, tuo 
tarpu spazminis hemipleginis cerebrinis paralyžius užima antrą vietą pagal paplitimą po pirmaujančios formos ir sudaro 32 proc. VCP atvejų [14]. Mūsų tyrimo metu taip pat dominavo spazminio cerebrinio paralyžiaus formos: spazminè diplegija buvo nustatyta 56 proc., o spazminè hemiplegija -46 proc. vaiku.

Vaiko, sergančio cerebriniu paralyžiumi, gimimas susijęs su sunkiais tėvų ir artimujų emociniais išgyvenimais. T. Krstić ir kt. (2016) savo moksliniame darbe nustate, kad ketvirtadaliui motinų, auginančių cerebriniu paralyžiumi sergančius vaikus, nustatytas didelis depresijos laipsnis (nuo sunkios iki labai sunkios) $[15,16]$. Mūsų tyrimo apklausoje dalyvavę tévai buvo emociškai stabilios būklès. Nei vienam iš jų nebuvo nustatytas stiprus psichoemocinès būsenos sutrikimas. Panašią tendenciją rodo ir Ž. Rympo [17] atliktas tyrimas, parodęs, kad didesnè dalis (89 proc.) tèvų, auginančių neigalų vaiką, nesijaučia vieniši, nejaučia baimès dèl vaiko ateities ( 78 proc.). Diagnozuota vaiko negalia nesumenkino tėvų savivertės (91 proc.) ir gyvenimo prasmès jausmo (90 proc.). Dauguma mūsų tiriamujjų nurodè, kad jiems nebūdinga depresija (78 proc.), kad jie (84 proc.) nepyksta ant aplinkinių dèl vaiko sveikatos būklès. Mūsų tyrimo metu buvo siekiama išsiaiškinti, ar mieste gyvenančių tėvų psichoemocinè būklẻ yra reikšmingai stabilesné, nei gyvenančių kaime. V. Antonovo [18] tyrimo rezultatai parodè, kad didžioji dalis tèvų (apie 70 proc.), gyvenančių kaimo vietovėse, patiria daugiau problemų tenkindami vaiku poreikius, nei mieste gyvenantys tèvai $(\mathrm{p} \leq 0,05)$. Mūsų tyrimo rezultatai psichoemocinès būklès skirtumo tarp mieste ir kaime gyvenančių tėvų neparodè.

Autoriai nustatė reikšmingą neigiamą ryšị tarp didesnio tèvų streso lygio ir nepasitenkinimo socialine parama $(\mathrm{r}=-0,37)(\mathrm{p} \leq 0,05)[19]$. Mūsų tyrimo rezultatai parodè, $\mathrm{kad}$ buvo gauta silpna teigiama koreliacija ir statistiškai patikimas ryšys tarp šeimos tarpusavio sąveikos ir didesnès gaunamos paramos $(\mathrm{r}=0,30)(\mathrm{p} \leq 0,05)$. Buvo nustatyta silpna, teigiama tiesinè, statistiškai reikšminga priklausomybe tarp fizinès (materialiosios) gerovès ir tèvų, auginančių cerebriniu paralyžiumi sergančius mokyklinio amžiaus vaikus, emocinès gerovès $(r=0,25)(p \leq 0,05)$. Kiti autoriai gavo vidutiniškai stiprų teigiamą ryšį tarp tèvų, auginančių ikimokyklinio amžiaus vaikus, fizinès (materialiosios) ir emocinès gerovès $(\mathrm{r}=0,49)(\mathrm{p} \leq 0,05)[10]$.

\section{Išvados}

1. Tẻvų, auginančių cerebriniu paralyžiumi sergančius mokyklinio amžiaus vaikus, psichoemocinè būklè buvo stabili. Nei vienam iš tèvų nebuvo nustatytas stiprus psichoemocinès būsenos sutrikimas.

2. Nustatyta, kad tėvų, auginančių cerebriniu paralyžiumi sergančius mokyklinio amžiaus vaikus, gyvenimo kokybė buvo patenkinama. Geriausiai tevai vertino savo šeimos tarpusavio sąveikos sriti, blogiausiai - emocinès gerovès sritį.

3. Nustatytos silpnos teigiamos tiesinès statistiškai reikšmingos sąsajos tarp tėvų, auginančių cerebriniu paralyžiumi sergančius vaikus, materialiosios gerovès ir gyvenimo kokybės $(r=0,37, p \leq 0,05)$, emocinès gerovès ir šeimos tarpusavio sąveikos $(r=0,31, p \leq 0,05)$ bei šeimos tarpusavio sąveikos ir didesnès gaunamos paramos $(\mathrm{r}=0,30, \mathrm{p} \leq 0,05)$.

\section{Literatūra}

1. Maestro-Gonzalez A, Bilbao-Leon MC, Zuazua-Rico D, Fernandez-Carreira JM, Baldonedo-Cernuda RF, Mosteiro-Diaz MP. Quality of life as assessed by adults with cerebral palsy. PLoS One 2018;13(2):29401489.

https://doi.org/10.1371/journal.pone.0191960

2. Mikulènaitė L., Petrulytė J., Žernakova A. Vaikų, sergančių cerebriniu paralyžiumi, ilgalaikio gydymo botulino toksinu poveikis čiurnos sąnario judesio amplitudei ir vaikų mobilumui. Sveikatos mokslai, 2015;25(1):58-65.

https://doi.org/10.5200/sm-hs.2015.010

3. Higienos instituto Sveikatos informacijos centras. Lietuvos gyventojų sveikata ir sveikatos priežiūros ịstaigų veikla. http:// www.hi.lt/lt/lietuvos-gyventoju-sveikata-ir-sveikatos-prieziuros-istaigu-veikla-2013-m.html

4. Shamsoddini A, Amirsalari S, Hollisaz MT, Rahimnia A, KhatibiAghda A. Management of spasticity in children with cerebral palsy. Iran J Pediatr 2014;24(4):345-51.

5. Diaman II, Chuyko YA. Correction of movement disorders of children with cerebral palsy with the help of innovative techniques. TSPU Bulletin 2014;142(1):136-40.

6. Jusienė R, Bagdonaitė L. Socialinės paramos ryšys su neigalius vaikus auginančių tėvų psichologiniu prisitaikymu. Socialinis darbas, 2004;3(1):105-115.

7. Ribeiro MMF, Sousa AL, Vandenberghe L, Porto CC. Parental stress in mothers of children and adolescents with cerebral palsy. Rev Lat Am Enfermagem 2014;22(3):440-447. https://doi.org/10.1590/0104-1169.3409.2435

8. Ustilaitė S, Kuginytè-Arlauskienė I, Cvetkova L. Šeimų, auginančių neịgalius vaikus, vidinio ir socialinio gyvenimo pokyčiai. Socialinis darbas, 2011;10(1):20-26.

9. Epifanio MS, Genna V, De Luca C, Roccella M, La Grutta S. Paternal and maternal transition to parenthood: the risk of postpartum depression and parenting stress. Pediatric Reports 2015;7(2):5872.

https://doi.org/10.4081/pr.2015.5872

10. Malkin MB. Šeimų, auginančių ikimokyklinio ir mokyklinio amžiaus vaiką su autizmo spektro sutrikimu, specialieji poreikiai ir gyvenimo kokybè. Magistro baigiamasis darbas, 2016.

11. Renger R. A review of the profile of mood states (POMS) in the prediction of athletic success. J of Appl Sport Psych 
1993;5(1):78-84.

https://doi.org/10.1080/10413209308411306

12. Epifanio MS, Genna V, De Luca C, Roccella M, La Grutta S. Paternal and maternal transition to parenthood: the risk of postpartum depression and parenting stress. Pediatric Reports 2015;7(2):38-44.

https://doi.org/10.4081/pr.2015.5872

13. Chiarello LA, Palisano RJ, Maggs JM, Orlin MN, Almasri N, Kang LJ, Chang HJ. Family priorities for activity and participation of children and youth with cerebral palsy. Physical Therapy 2010;90(9):1254-1264.

https://doi.org/10.2522/ptj.20090388

14. Jauhari P, Singhi P, Sankhyan N, Sankhyan N. A comparison of spastic diplegia in term and preterm born children. Journal of Child Neurology 2018;33(5):333-339. https://doi.org/10.1177/0883073817754175

15. Krstić T, Mihić L, Mihić I. Stress and resolution in mothers of children with cerebral palsy. Research in Developmental Disabilities 2016;51:188.

https://doi.org/10.1016/j.ridd.2016.02.002

16. Lee MH, Matthews AK, Park C. Determination of health related qualify of life among mothers of children with cerebral palsy. J Pediatr Nurs 2019;44:1-8.

https://doi.org/10.1016/j.pedn.2018.10.001

17. Rympo Ž. Šeimų, auginančių neịgalų vaiką, psichosocialiniai poreikiai ir problemos. Magistro baigiamasis darbas, 2011.

18. Антонов ВЛ. Потребности семей с детьми с ограниченными возможностями в процессе социальной реабилитации. VII Международная студенческая научная конференция, 2015. https://scienceforum.ru/2015/article/2015014469

19. Al-Gamal E, Long T. Psychological distress and perceived support among Jordanian parents living with a child with cerebral palsy: a cross-sectional study. Scand J Caring Sci 2013; 27:624-631.

https://doi.org/10.1111/j.1471-6712.2012.01071.x

\section{RELATIONSHIP BETWEEN PSYCHOEMOTIONAL STATE AND QUALITY OF LIFE IN PARENTS RAISING SCHOOL AGED CHILDREN WITH CEREBRAL PALSY

\author{
R. Dadelienė, E. Bartoševič, J. Kairys,
} R. Barčytė, J. Raistenskis}

Keywords: children with cerebral palsy, parents, special needs, quality of life, psychoemotional state.

Summary

The aim of research work: Reveal the relation between psychoemotional state and quality of life of parents, raising school aged children with cerebral palsy.

Material and methods: Were tested 68 parents raising school aged children with cerebral palsy. Methods used in the study: Family quality of life questionnaire; Profile of Mood States questionnaire. Statistics analysis R software and MS Excel 2010 were used for the statistical analyzation of the data in the study.

Results and conclusion: Psychoemotional status of the parents raising school age children with cerebral palsy was stable. None of the parents was diagnosed a strong psychoemotional disorder. It was determined that life quality of the parents raising school-age children with cerebral palsy was satisfactory. The parents assessed mutual interaction within their family the best, and emotional welfare - the worst. An analysis of the survey data revealed weak statistically significant linear correlations between material wellbeing of the parents raising children with cerebral palsy and quality of life $(\mathrm{r}=0,37, \mathrm{p} \leq 0,05)$, material welfare and visiting public places $(r=0,30, p \leq 0,05)$, emotional welfare and mutual interaction within one's family $(\mathrm{r}=0,31, \mathrm{p} \leq 0,05)$.

Correspondence to: ruta.dadeliene@mf.vu.lt

Gauta 2020-01-23 